\title{
The Imposition of Sanctions that Govern Pancasila for Juvenille Deliquency
}

\author{
Shinta Rukmi Budiastuti
}

\begin{abstract}
This study aims to look at the imposition of sanctions that govern Pancasila for juvenille deliquency. This study uses a historical approach on the grounds that there are changes and developments in the meaning and purpose of punishment from a view that was originally oriented towards traditional retributive views that saw criminal sanctions as punitive towards a more human or humanist conception of punishment by emphasizing the element of corrective action. crimes, namely children and a comparative juridical approach that is focused on the formulation of alternatives to child criminal sanctions in several KUHPs of foreign countries.

The results showed that the strategy of developing sanctions against children who committed crimes had been carried out through the enactment of Law No. 11 of 2012 concerning the Child Criminal Justice System three principles of punishment recognized in UUSPPA, namely the principle of criminal responsibility, the principle of the best interes of the child and the ultimum principle remidium. The three principles of punishment are also the basis of the formation of UUSPPA so that two punitive conditions apply for children in conflict with the law, namely the terms of absolute punishment and the conditions for relative punishment. The imposition of sanctions that affect the Pancasila for children who commit criminal acts in the form of verbal sanctions is considered more humanistic because with children's verbal sanctions avoid negative stigma that can affect the future of the child.
\end{abstract}

Index Terms: Imposition, Pancasila, Children, Juvenille Deliquency

\section{INTRODUCTION}

The state guarantees the right of every child to survival, growth and development and to protect them from violence and discrimination. The best interests of the child should be lived out as the best interests for the survival of the people, this is reinforced by the opinion. which aims to seek security, procurement and fulfillment of children's physical and spiritual well-being in accordance with their interests and human rights. (Darwan Prinst, 1997: 4) Arief Gosita said that, providing protection to children or adolescents is something that is natural and our shared responsibility. The protection of children from adolescents is nothing but the aim of ensuring that the welfare of children and adolescents is guaranteed and protection of the interests of the child can be achieved. All this must be done by all members of the community and become a shared responsibility. (Arief Gosita, 1985: 226)

Revised Manuscript Received on September 22, 2019

Shinta Rukmi Budiastuti,
Crimes involving children as perpetrators of crime are certainly not new things. Today there are many criminal incidents such as theft, mugging or extortion carried out by a child. Limitations on child delinquency are emphasized on child offenders which are acts that violate the norm, but if done by adults it is called crime, because it is unethical for child offenders to be called "criminals" children but juvenile delinquency because remembering the child who committed the crime supervision or coaching action. (Nasriana, 2011: 29) So that in the imposition of sanctions for children who commit a crime, sanctions should be imposed based on guidance for children in the future by considering the humanist side.

Humanitarian sanctions for children is deemed necessary because the child's future is still long. The legal treatment for children should get serious attention because after all this child is the future of a nation. Therefore, in making decisions, judges must be sure that the decisions taken will be a strong basis for returning and regulating children towards a better future to develop themselves as citizens responsible for the life of the nation. (Nasriana, 2011: 68)

Renewal of sanctions for children who commit crimes has developed because renewal of criminal law is based on and inspired by the will that is firm and confident and grows in society in accordance with the philosophy of Pancasila and the 1945 Constitution so that law enforcement in Indonesia is more humane in the future. satisfy all parties.

Pancasila as a spirit, principle or foundation that is born of the values that live in the Indonesian society and nation, the formation of a rule of law and the legal system and the operation of the legal system must be sourced and based on the values of the Pancasila. able to become the foundation for a just and dignified society. So that Indonesian law functions as a protector. (Teguh Prasetyo, 2013: 92)

\section{LITERATURE REVIEW}

The development of criminal sanctions in Indonesia raises questions about the nature of punishment. As a nation that has the Pancasila philosophy, criminal sanctions must be carried out using the Pancasila perspective to formulate what is good and right for the people of Indonesia. Various reforms of criminal sanctions in Indonesia have never been separated from the controversy that was influenced by humanitarian developments, particularly towards the renewal of criminal sanctions submitted in the 2012 Criminal Code Bill. 
As a nation that has Pancasila as a philosophy of life, criminal sanctions are part of the criminal law system from the national legal system oriented to Pancasila which contains a balance between religious morality (divinity), humanity (humanistic), nationality, democracy, and social justice (Barda Nawawi Arief ,: Bandung). Therefore, in carrying out renewal of criminal sanctions, it is necessary to review and explore national values that originate from the Pancasila.

The post-independence of Indonesia which had the Pancasila philosophy so that the purpose of punishment must be adjusted by putting forward the principles of punishment in the view of Pancasila philosophy carried out in accordance with the culture adopted by the Indonesian people by taking into account the following principles.

Recognition of humans as creatures of God Almighty so that the form of punishment must not conflict with religious beliefs or beliefs held by the people of Indonesia. Criminalization of a person must be directed at awareness of the faith of the convicted person so that he can repent to become a man of faith and obedience. In this case, punishment must function as a mental formation of convicted people and transform convicts into religious people (Sahetapy, J. E.; 1982).;Recognition of the dignity of human dignity as God's creation. Criminalization must not injure the most basic human rights and guarantee the right to life. This right is a right that cannot be reduced under any circumstances (non derogable right) and may not be degrading for any reason. The implication is that even though the convict is in a correctional institution, the elements and characteristics of his person must not be excluded in order to free the person concerned from his thoughts, traits, habits, and bad behavior. .; National solidarity with other people as fellow citizens. Actors must be directed at efforts to increase tolerance with others, foster leadership towards the interests of the nation, and direct them to not commit crimes. In other words, punishment needs to be directed at instilling a sense of love for the nation;Growing maturity as a citizen who is devout, able to control himself, discipline, and respect, and obey the law as a manifestation of people's decisions ;Raising awareness of the obligation of each individual as a social being who upholds justice with other people as fellow citizens. It should be borne in mind that the government and the people must be partially responsible for freeing convicts from the chaos and cruelty of social reality which entangles them as perpetrators of crimes (Sahetapy, J. E.,: 1982).

This shows that Indonesia has a provision of justice that is manifested in the Pancasila precepts which can provide views on how Indonesian people should be. It is not only lived out, but also always tried and described so that the values of Pancasila are always inherent in human beings themselves. Pancasila needs to be encouraged even more clearly and more concretely so that a legal society with Pancasila justice can be realized Pancasila as a basic idea so that law enforcement in Indonesia is more humanist so that criminal law is able to satisfy all parties, for children as perpetrators of crime, develop a new paradigm, namely the paradigm of decriminalization of children. This paradigm requires an action to liberate children from all criminal perspectives, from examinations, investigations, investigations to denial of children. To get to the new paradigm of decriminalization of children, it should practice progressive law, namely law that is intended for humanity and humanity, and not otherwise humans and humanity serve the law.

The paradigm of juvenile justice must be based on a child protection perspective. In the protection of children there are 4 basic principles, namely: non-discrimination; the best interests of the child; survival, growth and development, appreciation of children's opinions. Thus, in the perspective of child protection, there is no punishment for children and no prison for children. Whatever the reason, whatever the actions taken by the child. the process of punishment, especially imprisonment, only for adults.

In the law on the juvenile justice system, the new thing is one of the efforts of judges in handling juvenile cases in court by emphasizing in two ways, namely:

\section{A. Restorative Justice}

It is the settlement of criminal offenses by involving the perpetrators, victims, families of the perpetrators / victims and other related parties to jointly seek a fair solution by emphasizing recovery back to its original state and not retaliation (Article 1 Number6)

\section{B. Diversion}

Transfer of settlement of child cases from criminal justice processes to processes outside of criminal justice outside criminal justice (article 1 point 7). Basically, this diversion is carried out at the level of investigation, prosecution and criminal court hearings in the trial of the dam and is carried out in the event of a criminal offense committed under a sentence of imprisonment under 7 (seven) years and not a residual crime. In addition, the basic nature of the diversion is aimed at achieving peace between victims and children in resolving child cases outside the judicial process, avoiding children from deprivation of independence, encouraging people to participate and instilling a sense of responsibility to children.

In these two efforts, the judge acts as a mediator to mediate on the problems of children who have problems with the law and are expected to be able to reach a fair and impartial agreement. Every child deprived of his independence must be treated humanely and respected for his human dignity. Children deprived of independence must be separated from adults, unless they are considered as the best thing for the child concerned

\section{RESEARCH METHODS}

This research was conducted in the Surakarta District Court, Sukoharjo, Boyolali, Karanganyar and Surakarta Pemasyarakatan (BAPAS). and Engin IJTRE 
This research is descriptive analytical because it wants to reveal legislation relating to legal theories that are the object of research. Likewise the law in its implementation in the community relating to the object of research.

The nature of this study is intended to obtain a comprehensive picture and is intended to explore and provide clarification on the basic idea of the determination of action as an alternative sanction that is humanist for children in the renewal of criminal law in Indonesia.

In accordance with the type of research that is normative juridical, this study is dominant using secondary data in addition to primary data as complementary or explanatory to secondary data. Secondary data includes primary legal materials, secondary law and tertiary legal materials. Primary legal materials, namely legal materials that are binding in the form of laws and regulations relating to the object of research. Primary legal material is an authoritative legal material which means having authority. Primary legal materials consist of legislation, official records or minutes in the making of legislation and judges' decisions. (Amiruddin and H. Zainal Asikin, 2004: 118)

The technique of collecting data is done through library research and literature study is a technique to obtain secondary data in the form of legislation, scholarly scientific work and other sources. The interviewing technique is done to obtain supporting data in order to complete the information needed in answering research problems, by holding questions and answers (interviews) on various law enforcement officials who understand the problems regarding child criminalization.

The data that has been obtained is analyzed qualitatively by decoding descriptively and prescriptively. Selected data is made in a list in the form of a summary, to be combined so that it is arranged in the form of systematic words. As the last activity the researcher conducted a re-examination to be able to make conclusions through a description of what was successfully understood from the research problem. The researcher tries to draw empirical data or information to the level of abstraction in the form of theoretical meaningful statements.

From the description of the data and analysis carried out based on the appropriate theories, it can be shown what the witness of the Pancasila is like for a child who commits a crime

\section{RESULT AND FINDING}

Law No. 11 of 2012 concerning the Criminal Justice System of Children does not follow the provisions of criminal sanctions contained in Article 71 up to Article 81. Crimes that can be imposed on children who commit criminal acts according to Law Number 11 of 2012 include: Basic Crimes and Additional Criminal Cases. Main Crimes consist of: criminal warning; criminal terms: Coaching outside the institution; Society service; or Supervision;work training; coaching in institutions; and jail. While additional criminal consists of: deprivation of profits derived from criminal acts; or fulfillment of customary obligations.
Crimes imposed on children are prohibited from violating the dignity of the child. Further provisions regarding the forms and procedures for implementing criminal acts as referred to in paragraph (1), paragraph (2), and paragraph (3) are regulated by Government Regulation.

Arrangements regarding sanctions for action in Law No. 11 of 2012 concerning the Child Criminal Justice System regulated in, Article 82, consisting of: return to parents / guardians; surrender to someone; mental hospital care; care at LPKS; obligation to attend formal education and / or training held by the government or private entity; revocation of driving license; and / or repairs due to criminal acts.

The birth of Law No. 11 of 2012 concerning the Criminal Justice System for Children (SPPA Law) provides very high hopes for the Ministry of Law and Human Rights (c.q. Directorate General of Corrections) to immediately strengthen the existence of the Correctional Center in the judicial process. This is none other than because the SPPA Law provides such a large role for the Correctional Center (Bapas) in handling children facing the law.

This SPPA Law regulates clearly and decisively the role that must, even in some roles having a "mandatory" gradation, be carried out by Bapas. The role carried out by Bapas moves from the investigation phase to the stage of guidance after undergoing a crime. The SPPA Law is to promote fair recovery and avoid children from the process of justice, therefore Article 7 paragraph (1) states that at the level of investigation, prosecution and examination of cases of children in the district court it is mandatory Diversion is sought.

It should be understood that not all types of criminal acts can be carried out by Diversion. This diversion is carried out in the event that a crime is committed: threatened with imprisonment under 7 (seven) years; and not a repetition of a crime. If a child's case must be included in a judicial process, Bapas (in this case the Community Supervisor) or other counselor in accordance with the provisions of the legislation has an obligation to provide assistance to children at each level of examination (see Article 23 paragraph (1)).

The Birth of the Republic of Indonesia Law Number 11 Year 2012 concerning the Child Criminal Justice System At least provides a new nuance in the handling of children in conflict with the law. This law is considered capable of representing a restorative justice approach with a diversion mechanism. However diversion is implemented in law. This juvenile criminal justice system is carried out at every stage of the judicial process. This obviously will not be able to avoid the negative stigmatization process for children because the stigmatization process of children in conflict with the law starts when children deal with the police.

The diversion process carried out in the prosecution and trial process is not able to avoid the negative stigma of children because the child has gone through a judicial process and even this process takes a long time and costs are high. 
Therefore it is necessary to review the placement of diversion processes in each stage of the juvenile justice system and the significance of the use of warnings and informal diversions as a solution to avoid high costs and long processes in the implementation of formal diversion

Article 5 of Law Number 11 of 2012 concerning the Child Criminal Justice System is a form of affirmation of the use of a restorative approach to the restorative justice model. In this article it is stated: (1) Child Criminal Justice System must prioritize the Restorative Justice approach. (2) Child Criminal Justice System as referred to in paragraph (1) includes: a. Investigation and criminal prosecution carried out in accordance with the provisions of the laws and regulations, unless otherwise stipulated in this law; b. Child trials conducted by courts in the general court environment; and c. Guidance, guidance, supervision, and / or assistance during the process of implementing criminal acts or actions and after undergoing criminal action. (3) In the Child Criminal Justice System as referred to in paragraph (2) letters $\mathrm{a}$ and $\mathrm{b}$, Diversionmust be sought. The definition of restorative justice is explained in article 1 point 6 where Restorative Justice is the settlement of criminal cases by involving perpetrators, victims, families of perpetrators / victims, and other parties involved to jointly seek solutions just by emphasizing recovery back to its original state, and not revenge. Handling carried out by calculating the broader influence of victims, actors and communities is carried out through a diversion mechanism, while diversion itself in the comments of Rule 11.1 The Beijing Rules are as follows: diversion involves the transfer of criminal justice processes and, often, directed to community support services, generally carried out formally and informally in many legal systems. This practice serves to prevent the negative effects of subsequent processes in juvenile justice administration (eg the stigma of decisions and penalties). in many cases, non-intervention will be the best response. Thus, diversion at the outset and without reference to alternative (social) services might be an optimal response. This is especially the case where violations are not serious and where families, schools or other informal social control institutions have reacted, or tend to react, in an appropriate and constructive manner.

In article 5 paragraph 3 of Law Number 11 of 2012 concerning the juvenile justice system it is stated that at the level of investigation, prosecution and examination of cases of children in a district court, diversion must be sought. As for more specifically, criminal acts that must be sought for diversion regulated in article 7 where explained as follows (1) At the level of investigation, prosecution and examination of cases, Children in the district court must seek Diversion. (2) Diversion as referred to in paragraph (1) is carried out in the event of a criminal offense committed: a. threatened with imprisonment under 7 (seven) years; and b. not a repetition of a crime. If it is associated with the definition of diversion in international child instruments above,there is a different understanding in understanding diversion. Diversion in the law on the juvenile justice system is interpreted as a process of transfer that can be carried out at every stage of the juvenile justice system. While the diversion in the Beijing Rule is intended to avoid children from the formal process of criminal justice which provides a negative stigma for children. Furthermore, it was emphasized in the Beijing Rules 11.1 comment that diversion was intended to avoid negative stigma as long as children were processed in the juvenile justice system. The diversion must be done when children in conflict with the law make the first contact with investigators. able to run this diversion program properly.

In Article 8 paragraph 1 of the UUPSA, the diversion process is carried out through deliberation involving children and parents / guardians, victims and / or parents / guardians, community advisers and professional social workers based on a restorative justice approach, diversion can only be applied to violations that threatened with imprisonment under 7 (seven) years and not a repetition of a criminal offense. This shows, the diversion in the Child Criminal Justice System Law is carried out with only one formal model.

The mechanism of diversion as in the rule rule 11The Beijing Rules can be done through formal and informal mechanisms. Informal mechanisms can be given in the form of reprimand in the place where the violation is committed. Whereas the formal mechanism can be done with formal warning by the police or by a mechanism of deliberation involving victims, perpetrators, their families and related parties that are considered important to be presented.

The United Nations Minimum Standards for Non-Custodial Measures (TokyoRules) dated December 14, 1990, Rule 8 concerning the need to be considered in making decisions regarding the needs of guiding actors, protecting the community and the interests of victims, it was stated that coaching officials could apply sanctions in the form of verbal sanctions in the form of giving good advice (admonotion), reprimand, and warning. This needs to be done considering that if only the diversion mechanism is carried out by deliberation, it will take a lot of time with high costs. Therefore it is necessary to present a diversion with several models by adjusting the seriousness of the violation, the presence or absence of a corbiter the size of the loss suffered by the victim. This is very important in connection with the idea of recommending verbal sanction in the formulation of criminal law in Indonesia. From the arguments and criticisms raised above, it can be said that indeed so far the type of criminal imposed by the judge is solely based on the law without the freedom of the judge to make a choice, whether the crime is actually suitable for the perpetrator of the crime.The findings in this study of the development model of sanctions for pancasila discussion consist of optimizing the role of bapas with the imposition of verbal sentences in the form of giving good advice, reprimand (reprimand), and hard (warning). aimed at the interests of children to avoid negative stigma. 


\section{CONCLUSION}

The conclusions that can be taken based on the descriptions that have been submitted are as follows: The strategy for the development of criminal sanctions that affect the Pancasila for children who commit criminal acts is carried out by optimizing the role of bapas in the process of resolving criminal acts by children through community research and assistance so that the diversion process can be achieved which promotes restorative justice.

\section{SUGGESTION}

Suggestions that can be recommended based on the findings generated in this study are that the Government should The imposition of sanctions that affect the Pancasila for children who commit criminal acts in the form immediately prepare implementing regulations for the enactment of verbal sanctions as a humanist sanction development model for children who commit criminal acts in order to be able to apply more optimally.

\section{REFERENCE}

[1] Arief, Gosita, 1985,The Problem of Victims of Crime, Akademika Pressindo, Jakarta,

[2] Amiruddin dan H. Zainal Asikin,200, Introduction to Legal Research Methods , PT Raja Grafindo Persada, Jakarta

[3] Darwan Prinst. 1997. Indonesian Child Law, Citra Aditya Bakti Bandung

[4] Teguh Prasetyo,2013, Law and Legal System Based on Pancasila, Media Perkasa, Yogyakarta

[5] Nasriana,2011, Criminal Law Protection for Children in Indonesia , PT Raja Grafindo Persada, Jakarta

[6] UU no. 11 of 2012, concerning the Child Criminal Justice System

[7] Circular of the Republic of Indonesia Supreme Makamah (SEMA) No. 7 of 1985 concerning Implementation Guidelines for the Duty of Supervisory and Observing Judges

[8] Circular of the Republic of Indonesia Supreme Makamah (SEMA) No. MA / Kumdil / 31 / I / 2005 dated 11 January 2005 concerning Appointment of Judges of Children

[9] Court Decision No. 1 / PUU-VIII / 2010 concerning setting the age limit for children to protect children's constitutional rights, especially the right to protection and the right to grow and develop

[10] Court Decision No. 1 / PUU-VIII / 2010 concerning setting the age limit for children to protect children's constitutional rights, especially the right to protection and the right to grow and develop

[11] United Nations Standard Minimum Rules for Non-custodial Measures (TokyoRules)

[12] Standart Minimum Rules for The Administration of Juvenilles Justice (the Beijing Rules)

\section{AUTHOR PROFILE}

My name is Shinta Rukmi Budiastuti, my area of interest is political science and international relations. 